\title{
METODE PENEMUAN (INQUIRY) UNTUK MENINGKATKAN PEMAHAMAN SISWA DALAM MATA PELAJARAN MATEMATIKA
}

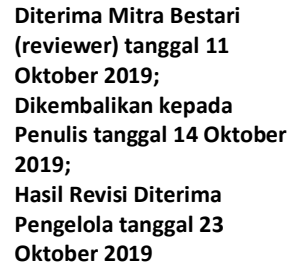

\begin{abstract}
Abstrak
Dunia pendidikan di abad ke-21 menghadapi tantangan yang tidak ringan, terutama di bidang ilmu pengetahuan dan teknologi yang sangat pesat.Perubahan masyarakat dunia maupun masyarakat kita sendiri dibidang sosial budaya dan berkembangnya isu bahwa kualitas pendidikan rendah.Oleh karena itu untuk menghadapi tantangan tersebut pendidikan dan pembelajaran perlu adanya perubahan baik kuantitas maupun kualitasnya.Berbagai upaya telah dilakukan dibidang pendidikan. Guru sebagai pelaksana langsung pencapaian tujuan pembelajaran perlu meningkatkan kualitas proses pembelajaran yaitu dengan memperhatikan bagaimana cara menyampaikan pengetahuan yang dimiliki itu kepada peserta didikanya. Metode penemuan pada pembelajaran matematika dimaksud untuk mendorong siswa dalam memahami sesuatu yang bersifat fakta atau relasi matematika yang masih baru bagi siswa,misalnya pola, sifat-sifat atau rumus tertentu.Setelah menemukan fakta/relasi siswa diminta untuk menarik suatu generasi dari apa yang mereka temukan sendiri.Metode Inquiry adalah metode yang mampu menggiring peserta didik untuk menyadari apa yang telah didapatkan selama belajar. Inquiry menempatkan peserta didik sebagai subyek belajar yang aktif. Sehingga Pembelajaran matematika dengan menggunakan metode penemuan (inquiry) dapat meningkatkan pemahaman siswa.
\end{abstract}

Kata Kunci : Metode penemuan (inquiry), Pemahaman siswa, Mata pelajaran Matematika

\section{A. PENDAHULUAN}

\section{Latar Belakang}

Memasuki abad ke-21 ini dunia pendidikan menghadapi tantangan yang tidak ringan, terutama di bidang Ilmu Pengetahuan dan Teknologi (IPTEK) yang sangat pesat.Perubahan masyarakat dunia maupun masyarakat kita sendiri di bidang sosial budaya dan berkembangnya isu bahwa kualitas pendidikan rendah.Oleh karena itu untuk menghadapi tantangan tersebut pendidikan dan pembelajaran perlu adanya perubahan baik kuantitas maupun kualitasnya. Berbagai upaya telah dilakukan di bidang pendidikan. Misalnya dikeluarkan Undang-undang Sistem Pendidikan Nasional Nomor 20 Tahun 2003 dan program pendidikan 9 tahun serta diberlakukannya Kurikulum Tingkat Satuan Pendidikan (KTSP) 
Namun satu hal yang penting yaitu guru sebagai pelaksana langsung pencapaian tujuan pembelajaran perlu meningkatkan kualitas proses pembelajaran yaitu dengan memperhatikan cara menyampaikan pengetahuan yang dimiliki itu kepada siswanya. (atau siswa, silakan konsisten).

$$
\text { Metode penemuan pada }
$$

pembelajaran matematika dimaksud untuk mendorong siswa dalam memahami sesuatu yang bersifat fakta atau relasi matematika yang masih baru bagi siswa, misalnya pola, sifat-sifat atau rumus tertentu. Setelah menemukan fakta/relasi siswa diminta untuk menarik suatu generasi dari apa yang mereka temukan sendiri.

\section{Rumusan Masalah}

Berdasarkan uraian latar belakang di atas dapat dirumuskan masalah sebagai berikut :

1. Bagaimana pembelajaran dengan menggunakan metode penemuan/inquiry dapat meningkatkan prestasi belajar siswa pada pelajaran matematika ?

2. Bagaimana meningkatkan pemahaman siswa terhadap materi pelajaran matematika dengan menggunakan metode penemuan/inquiry?

3. Bagaiman aktifitas siswa dalam pembelajaran matematika dengan metode penemuan/inquiry?

\section{Tujuan}

Berdasar permasalahan diatas maka tujuan makalah ini adalah sebagai berikut :

1. Untuk mengetahui bagaimana pembelajaran dengan menggunakan metode inkuiri dapat meningkatkan prestasi belajar siswa pada pelajaran matematika.

2. Untuk mengetahui bagaimana meningkatkan pemahaman siswa terhadap materi pembelajaran matematika dengan menggunakan metode inkuiri.

\section{Manfaat}

Makalah ini diharapkan bermanfaat bagi :

1. Guru

Guru akan memiliki gambaran tentang pembelajaran matematika yang efektif dan menyenangkan sehingga dapat mengidentifikasi permasalahn yang terjadi dikelas sekaligus dapat memecahkan permasaahan pembelajaran. Diharapkan dapat mengembangkan profesinya sehingga menjadi guru yang professional.

2. Siswa

Siswa akan mudah memahami materi pembelajaran sehingga menjadi aktif dan dapat meningkatkan belajarnya.melatih siswa dalam bekerja sama dalam memecahkan masalah.

3. Lembaga

Bagi lembaga diharapkan dapat dijadikan sebagai bahan masukan informasi tentang salah satu topik dan 
cara pembelajaran matematika pada siswa SD/MI dengan metode inquiry untuk mencapai tujuan pembelajaran.

\section{B. KAJIAN TEORI}

\section{Belajar dan Pembelajaran Matematika SD}

1. Belajar

Menurut R. Gagne (1989)belajar dapat didefinisikan sebagai suatu proses di mana suatu organisme berubah prilakunya sebagai akibat pengalaman belajar.Belajar dan mengajar merupakan dua konsep yang tidak dapat dipisahkan satu sama lain. Dua konsep ini menjadi terpadu dalam satu kegiatan di mana terjadi interaksi antara guru dan siswa,serta siswa dengan siswa pada saat pembelajaran ber langsung.

Adapun menurut Burton dalam Usman dan Setiawati(1993:4), belajar dapat diartikan sebagai perubahan tingkah laku pada diri individu berkat adanya interaksi antara individu dengan indivadu lain dan individu dengana lingkungannya sehingga mereka lebih mampu berinteraksi dengan lingkungannya.

Sementara menurut E.R.Hilgard (1962), belajar adalah suatu perubahan kegiatan reaksi terhadap lingkungan. Perubahan kegiatan yang dimaksud mencakup pengetahuan, kecakapan, tingkah laku, dan ini diperoleh melalui pelatihan, pembiasaan, pengalaman dan sebagainya.

2. Pembelajaran Matematika SD

Guru matematika SD mempunyai tugas yang kompleks yaitu memahami dengan baik materi yang akan diajarkan, memahami dan memanfaatkan dengan baik siswa belajar Matematika, memahami cara mengajarkan Matematika yang efektif, menggunkan cara-cara pembelajaran matematika.

Tujuan

pembelajaran matematika SD menurut kurikulum 2004 adalah mengembangkan kemampuan bernalar melalui kegiatan penyelidikan, ekxpositoris dan experiment sebagai alat pemecahan masalah melalui pola pikir dan model matematika serta sebagai alat komunikasi melalui symbol, table, grafik, diagram,dalam menjelaskan gagasan.

Teori belajar matematika untuk mengajar matematika di SD menurut Winata putra (2007:7) ada 6 teori yaitu sebagai berikut :

1. Teori Belajar William Brownel Anak-anak pasti memahami apa yang sedang mereka pelajari jika belajar secara permanen atau terus menerus untuk waktu yang lama.

Salah satu cara bagi siswa untuk mengembangkan pemahaman tentang matematika adalah dengan 
menggunakan

benda-benda

tertentu ketika mereka mempelajari konsep matematika.

2. Teori Belajar Zolton P.Dienes

Dengan menggunakan berbagai sajian tentang suatu konsep matematika,anak-anak akan dapat memahami secara penuh konsep tersebut jika hanya dibandingkan dengan satu macam sajian.

3. Teori belajar Jean Piaget

Perkembangan mental setiap pribadi melewati 4 tahap, yaitu tahap sensori motor, tahap praoperasional, tahp opersaikongrit, dan tahap opersai formal.

4. Teori belajar Albert Bandura Belajar yang menekankan pada perolehan kompleks moderet behavior atau perilaku yang diteladani beserta konsekuensinya terhadap individu.

5. Teori Jeremi S.Bruner

Metode belajar merupakan factor yang menentukan dalam pembelajaran dibandingkan dengan pemerolehan suatu kemampuan khusus. Metode yang sangat didukung oleh Jeremi S.bruner adalah metode belajar dengan penemuan (inkuiri).

6. Teori belajar Robert M.Gagne Hasil belajar lebih penting dari pada proses belajar. Tujuan pembelajaran adalah pemerolehan kemampuankemampuan yang telah dideskripsikan secara khusus dan dinyatakan istilah istilah tingkah laku.

\section{Metode Inquiry}

Metode Inquiry adalah metode yang mampu menggiring peserta didik untuk menydari apa yang telah didapatkan selama belajar. Inquiry menempatkan peserta didik sebagai subyek belajar yang aktif Mulyasa (2003: 234). Kosasih Djahiri (1978/1979:128), mengemukakan pendapat yang senada tentang pengertian inquiry. Metode inquiry menurut Suryosubroto (2002:192) adalah perluasan proses diskoferi yang digunakan lebih mendalam. Artinya proses inquiry mengandung proses mental yang lebih tinggi tingkatanya, misalnya merumuskan problema, merancang eksperimen, melakukan eksperimen, mengumpulkan dan menganalisa data, menarik kesimpulan dan sebagainya.

Inquiry adalah salah satu cara belajar atau penelaahan sesuatu yang bersifat mencari sesuatu secara kritis, analitis, dan argumental (ilmiah) dengan menggunakan langkah-langkah tertentu menuju suatu kesimpulan (keyakinan) yang meyakinkan karena didukung oleh data, kenyataan, dan argumen. 


\section{METODE PENELITIAN}

Penelitian ini menggunakan desain penelitian literatur. Penulis mengumpulkan berbagai macam literatur baik berupa buku maupun buku elektronik.

\section{PEMBAHASAN}

\section{Cara-cara Pembelajaran Matematika}

Cara-cara

pembelajaran

matematika di sekolah dasar yang dianggap sesuai saat ini menurut Mahsetyo (2007:26) adalah sebagai berikut :

1. Problem Solving/ pemecahan masalah Ciri utama problem solving adalah adanya masalah yang tidak rutin (non routine problem) pada awalnya pembelajaran ini mengalami kesulitan mengerjakanya namun seterusnya menjadi terbiasa dan cerdas dalam memecahkan masalah setelah memperoleh banyak latihan.

2. Investigation

Matematika investigation adalah penyelidikan matematka tentang masalah yang dapat dikembangkan menjadi model matematika berpusat pada tema tertentu, berorientasi pada kajian atau eksplorasi mendalam dan bersifat open ended. Kegiatan belajar dapat berupa cooperative learning.

3. Kontekstual learning

$\begin{array}{llr}\text { Kontekstual } & \text { learning adalah } \\ \text { peneglolaan } & \text { suasana belajar yang }\end{array}$

mengaitkan bahan pelajaran dengan situasi dan atau kehidupan sehari-hari, hal-hal yang factual atau keadaan nyata yang dialami siswa.

4. Inquiry

Metode pembelajaran ini mendorong siswa untuk memahami suatu fakta atau relasi matematika dalam mengkaji dan menemukan sendiri sehingga siswa dapat menarik kesimpulan sendiri.

\section{Proses Belajar Mengajar Matematika}

Proses belajar mengajar merupakan proses interaksi antara siswa dengan guru dalam rangka mencapai tujuan pembelajaran. Belajar merupakan proses aktif dalam memperoleh pengalaman atau pengetahuan baru sehingga menyebabkan perubahan tingkah laku. Belajar adalah proses yang dilakukan oleh manusia untuk mendapatkan aneka ragam kemampuan, keterampilan dan sikap. Belajar didefinisikan seabgai perubahan dalam pengetahuan atau perilaku yang dihasilkan oleh pengalaman, perubahan tidak terjadi semata-semata terjadi melalui maturasi atau kondisi-kondisi bersifat sementara. Dari beberapa pengertian diatas, belajar pada dasarnya adalah proses perubahan tingkah laku berkat adanya pengalaman. Perubahan yang terjadi dalam diri seseorang banyak sekali baik sifat maupun jenisnya, oleh karena itu sudah 
tentu tidak setiap perubahan dalam diri seseorang merupakan perubahan dalam arti belajar. Adapun ciri-ciri perubahan tingkah laku dalam arti belajar adalah perubahan terjadi secara sadar, bersifat kontinyu dan fungsional, positif dan aktif bukan bersifat sementara, perubahan tersebut bertujuan dan terarah serta mencakup seluruh aspek tingkah laku. Mengajar merupakan proses aktif guru untuk membimbing siswa dalam mempelajari dan memahami konsepkonsep yang dikembangkan dalam proses belajar mengajar (arifin, 2003:8). Karena kegiatan belajar merupakan hal yang wajib dikerjakan individu, maka guru hendaknya memberikan bimbingan dan dorongan pada siswa agar timbul motivasi pada diri siswa sebagai motifasi extrinsic. Selanjutnya mengajar adalah usaha untuk mengkoordinasikan lingkunganya dengan siswa dan bahan pengajaran sehingga menimbulkan proses belajar pada siswa. Dari pendapat tersebut mengajar merupakan suatu kegiatan atau proses yang menyediakan kondisi yang merangsang kegiatan belajar siswa untuk memperoleh pengetahuan, keterampilan dan sikap nilai- nilai tertentu.

Pembelajaran matematika adalah proses pemberian pengalaman belajar kepada siswa melalui serangkaian kegiatan yang terencana sehingga siswa memperoleh kompetensi tentang materi matematika yang dipelajari.

Salah satu komponen yang menentukan ketercapaian kompetensi adalah penggunaan strategi pembelajaran matematika yang sesuai dengan :

1. Topik yang sesuai dengan yang dibicarakan.

2. Tingkat perkembangan intelektual siswa.

3. Prinsip dan teori belajar

4. Keterlibatan aktif siswa.

5. Keterkaitan dengan kehidupan siswa sehari-hari.

6. Pengembangan dan pemahaman pelajaran matematis

Ciri atau prinsip dalam proses agar siswa mempunyai kompetensi yang sesuai dengan tuntutan perkembangan saat ini dan mendatang adalah :

1. Berorientasi pada siswa.

2. Mengembangkan strategi pembelajaran.

3. Memperhatikan teori pendidikan dan teori belajar.

4. Mengusahakan suasana yang demokratis, partisipasif, dan kooperatif.

5. Mengembangkan penilaian (evaluasi) yang menyeluruh dan beragam.

6. Memperhatikan ciri pokok keilmuan dari bidang studi atau materi yang sedang dipelajari. 
Untuk mendukung usaha pembelajaran yang mampu menumbuhkan kekuatan matematikal diperlukan guru yang profesional dan kompeten. Guru yang profesional dan guru yang kompeten adalah guru yang menguasai materi pembelajaran matematika, memahami bagaimana anak-anak belajar. Menguasai pembelajaran yang mampu mencerdaskan peserta didik, dan mempunyai kepribadian yang dinamis dalam membuat keputusan perencanaan dan pelaksanaan pembelajaran.

Guru matematika yang profesional dan kompeten mempunyai wawasan landasan yang dapat dipakai dalam perencanaan dan pelaksanaan pembelajaran matematika. Wawasan itu berupa dasar-dasar teori belajar yang diterapkan untuk mengembangkan dan perbaikan pembelajaran matematika.

\section{Metode pembelajaran Inquiry}

Metode inquiry adalah cara penyampaian bahan pengajaran dengan memberikan kesempatan kepada siswa untuk belajar mengembangkan potensi intelektualnya dalam jalinan kegiatan kegiatan yang disusunya sendiri untuk menemukan sesuatu. Siswa didorong untuk bertindak aktif mencari jawaban atas masalah-masalah yang dihadapinya dan menarik kesimpulan sendiri melalui proses berfikir ilmiah yang kritis, logis, dan sistematis, sedangkan guru hanya bertindak sebagai fasitator, motivator dan informan saja. Sudah barang tentu sebelum mampu melakukan kegiatan itu siswa memerlukan petunjuk dan latihan mengenai berbagai teknik inquiry secara baik. Untuk melakukan metode inquiry guru harus memliki 6 ciri guru inquiry (Kosasih,1978:46-47), yaitu :

a. Memiliki kemampuan sebagai perencana (planers), baik perencana program pengajaran, pelaksanaan, dan evaluasi maupun kegiatan lainnya.

b. Memiliki kemampuan untuk melaksanakan rencana itu dengan sebaik-baiknya menurut keputusan proses mengajar bidang setudi masing-masing serta tercapainya tujuan instruksional.

c. Memiliki kemampuan sebagai penanya dimana guru mempersiapkan sejumlah kunci pertanyaan yang akan menstimulus pikiran analitis kritis dari siswanya.

d. Memiliki kemampuan sebagai manager

e. Memiliki kemampuan sebagai pemberi hadiah dapat berupa pujian yang bersifat posisitf untuk meningkatkan motifasi belajar.

f. Kemampuan sebagai penguji kebenaran dari pada suatu sistem nilai 
Metode inquiry menurut Roestiyah (2001:75) merupakan suatu teknik atau cara yang digunakan guru untuk mengajar di depan kelas, dimana guru membagi tugas meneliti suatu masalah ke kelas. Siswa dibagi menjadi beberapa kelompok dan masing-masing kelompok mendapat tugas tertentu yang harus dikerjakan, kemudian mereka mempelajari, meneliti, atau membahas tugasnya didalam kelompok. Setelah hasil kerja mereka di dalam kelompok didiskusikan, kemudian dibuat laporan yang tersusun dengan baik. Akhirnya hasil laporan dilaporkan kesidang pleno, dan terjadilah diskusi secara luas dari sidang pleno kesimpulan akan dirumuskan sebagai kelanjutan hasil kerja kelompok. Dan kesimpulan yang terakhir bila masih ada tindak lanjut yang harus dilaksanakan, hal itu perlu diperhatikan.

Prinsip dan norma yang dikandung dalam metode inquiry adalah kerjasama, kebebasan intelektual dan kesamaan derajat. Selanjutnya menyatakan bahwa selama proses pembelajaran siswa berinteraksi dengan siswa lain dan juga dengan gurunya.

Di sisi lain ketepatan belajar dalam metode inquiry berkenaan dengan efektifitas dan efisiensi. Efektivitas berkenaan dengan tujuan yang hendak dicapai ,sedang efisiensi berkenaan dengan ketepatan waktu dan kemudahan dalam pelaksanaan.
Guru menggunakan teknik bila mempunyai tujuan agar siswa terangsang oleh tugas dan aktif mencari serta meneliti sendiri pemecahan masalah itu. Mencari sumber sendiri, dan mereka belajar bersama dalam kelompoknya. Diharapkan siswa juga mampu mengemukakan pendapatnya dan merumuskan kesimpulan nantinya juga mereka diharapkan dapat berdebat, menyanggah dan mempertahankan pendapatnya. Inquiry mengandung proses mental yang lebih tinggi tingkatanya, seperti merumuskan masalah, merencanakan ekxperimen, melakukan ekxperimen, mengumpulkan dan menganalisa data, menarik kesimpulan. Pada metode inquiry dapat ditumbuhkan sikap obyektif, jujur, hasrat ingin tahu, terbuka, dan lain sebagainya.

Dari uraian diatas maka untuk melihat efektifitas metode inquiry dilakukan evaluasi berdasarkan aktifitas siswa selama melakukan inquiry. Aktifitas siswa ini meliputi ketertarikan, kesungguhan, antusiasme, berani mengemukakan pendapat, baik pada guru maupun siswa lain., menghargai pendapat orang lain serta keceriaan.

Akhirnya dapat mencapai kesimpulan yang ditujui bersama. Bila siswa melakukan semua kegiatan diatas berarti siswa sedang melakukan inquiry.

Teknik inquiry ini memiliki keunggulan yaitu : 
a. Dapat membentuk dan mengembangkan konsep dasar kepada siswa, sehingga siswa dapat mengerti tentang konsep dasar ide-ide dengan lebih baik;

b. Membantu dalam menggunakan ingatan dan transfer pada situasi proses belajar yang baru;

c. Mendorong siswa untuk berfikir dan bekerja atas inisiatifnya sendiri, bersifat jujur, obyektif, dan terbuka;

d. Mendorong siswa untuk berfikir intuitisdan merumuskan hipotesanya sendiri;

e. Memberi kepuasan yang bersifat intrinsik;

f. Situasi pembelajaran lebih menggairahkan;

g. Dapat mengembangkan bakat atau kecakapan individu;

h. Memberi kebebasan siswa untuk belajar sendiri;

i. Menghindarkan diri dari cara belajar tradisional;

j. Dapat memberikan waktu kepada siswa secukupnya sehingga mereka dapat mengasimilasi dan mengakomodasi informasi.

\section{Manfaat Atau Kegunaan Metode inquiry} Metode inquiry mempunyai kegunaan atau manfaat sebagai berikut :

a. Mengembangkan sikap keterampilan siswa untuk mampu memecahkan

permasalahn dan mengambil keputusan secara obyektif dan mandiri;

b. Mengembangkan kemampuan berfikir siswa atau meningkatkan potensi intelektual;

c. Membina pengembangan sikap penasaran (ingin tahu lebih jauh) dan cara berfikir obyektif, mandiri, kritis, logis, analitis baik secara individual maupun kelompok;

d. Bertambahnya kemampuan untuk mengerti tentang melacak kembali (heuristic) dari discovery dimana discoferi akan merupakan cara berfikir dan cara hidup dalam menghadapi segala masalah atau keadaan discoferi.

e. Dengan dikuasai metode inquirydiscovery atau pemecahan masalah dapat menjadi alat bantu dalam mengingat sesuatu. Dengan alat bantu siswa dapat mengorganisasikan bahan sedemikian rupa sehungga dapat diingat dan ditemukan kembali dan tidak hanya menjadi barang simpanan saja.

\section{Pedoman Untuk Menciptakan Iklim inquiry}

Agar iklim inquiry dalam kelas atau kelompok dapat berhasil dengan baik, Jhon Jarolimek dan MH. Walch mengemukakan beberapa pedoman sebagai berikut :

a. Kelas diarahkan kepada pokok permasalahan yang telah jelas 
rumusanya, patokan cara inquiry, dan arah tujuannya;

b. Agar dipahami bahwa inquiry adalah pengembangan kemampuan membuat perkiraan serta proses berfikir. Peranan pertanyaan dan kemampuan mengemukakan pertanyaan (teknik Bertanya) dari guru akan sangat menentukan keberhasilan inquiry;

c. Hendaknya diberikan keluasaan kepada siswa untuk mengemukakakan berbagai kemungkinan (alternative) dalam bertanya atau menjawab;

d. Cara menjawab dapat diutarakan dalam berbagai cara, sepanjang hal ini mengenai permasalahan yang sedang di-inquiry;

e. Pada umumnya inquiry menggali nilainilai atau sikap, oleh karenanya hormatilah, dan hargailah system kepercayaan atau nilai dan sikap siswa;

f. Guru hendaknya menjaga diri untuk tidak menjawab pertanyaan pertanyaan;

g. Usahakan selalu jawaban bersifat merata dan komparatif (dapat dibandingkan dengan lainya

\section{Langkah-langkah Metode inquiry}

Langkah-langkah metode inquiry dalam kelompok kecil (small Group inquiry) dapat dijelaskan sebagai berikut :

a. Membina suasana yang responsif

Dalam hal ini kegiatan guru adalah menjelaskan arti dan proses inquiry, sedangkan siswa memperhatikan penjelasan guru dan bertanya apabila belum jelas. Guru akan mengajukan pertanyaan yang harus dijawab oleh siswa dengan "ya atau tidak " memberi contoh hal tersebut beberapa soal.

b. Mengemukakan permasalah untuk di inquiry.

Dalam langkah ini harus dijaga agar guru tidak menjawab sendiri pertanyaan-pertanyaan

permasalahannya tetapi arahkanlah atau binalah agar siswa dapat menjawabnya.

Kegiatan guru adalah melemparkan permasalahan melalui ceritera, film, gambar, dan lain-lain. Kemudian mengajukan pertanyaan tersebut kearah mencari, merumuskan dan memperjelas permasalahan dari cerita, film, gambar tadi. Tanya jawab berhenti apabila masalah sudah terumuskan dan jelas.

Siswa : memperhatikan, menganalisis, merumuskan dan menjawab.

c. Pertanyaan-pertanyaan siswa Siswa : mengajukan pertanyaan yang sifatnya mencari atau mengajukan informasi atau data tentang masalah tersebut.

Guru : hanya menjawab "ya atau tidak “ atau seperlunya mengarahkan pertanyaan pada permasalahannya.

d. Merumuskan Hipotesis (asumsi atau pemikiran yang diperkirakan 
merupakan jawaban daripada permasalahan tersebut. Perkiraan ini nanti akan terlihat terbukti atau tidaknya pada saat pengumpulan dan pembuktian data).

Siswa : mencoba merumuskan hipotesis permasalahan tersebut (tentang sebab atau sebab pemecahan permasalahan tersebut).

Guru : membantu dan mengarahkan dalam bentuk pertanyaan atau pancingan.

e. Menguji Hipotesis.

Guru : mengajukan pertanyaan yang bersifat meminta data, membuktikan dan pembuktian data.

Siswa : menjawab dan memberikan data, selanjutnya membuktikan data serta kebenaranya.

Langkah - langkah diatas akan lebih sempurna apabila kemudian diakhiri dengan pengambilan kesimpulan dan perumusan-perumusan.

Kegiatan ini dilakukan oleh guru bersama siswa.

\section{Keunggulan Metode Inquiry.}

a. Mengembangkan sikap keterampilan siswa untuk mampu memecahan permasalahan serta mengambil keputusan secara obyektif dan mandiri;

b. Meningkatkan potensi intelektual siswa;

c. Dengan dikuasainya metode inquiry dapat menjadi alat bantu dalam mengingat sesuatu; d. Membina pengembangan sikap penasaran (ingin tahu lebih jauh) dan cara berpikir obyektif, mandiri, kritis, logis, analitis baik secara individu maupun secra kelompok.

\section{Kelemahan Metode inquiry}

a. Terlalu menekankan pada aspek intelektual atau kognitif, dan mengabaikan aspek afektif atau aspek emosional dalam proses belajar mengajar;

b. Hanya dapat mencari satu pengertian;

c. Jalannya pelajaran agak lambat;

d. Kelas yang besar menimbulkan kegaduhan.

\section{PENUTUP}

\section{Simpulan}

Dari Pembahasan di atas dapat diambil kesimpulan sebagai berikut :

1. Pembelajaran matematika dengan menggunakan metode penemuan (inquiry) dapat meningkatkan kemampuan prestasi siswa;

2. Pemahaman siswa terhadap materi pelajaran matematika dengan metode penemuan mengalami peningkatan;

3. Aktifitas siswa dalam pembelajaran matematika dengan model pembelajaran kooperatif dapat muncul dan berkembang.

Dengan menggunakan metode penemuan dapat melatih dan mendorong siswa dalam menemukan suatu fakta atau relasi yang belum diketahui. 


\section{Saran}

Dari kesimpulan diatas dapat disarankan hal-hal sebagai berikut :

1. Kegiatan pembelajaran matematika yang selama ini menggunakan metode kurang meningkat prestasi belajar siswa, keaktifan siswa dan pemahaman terhadap materi sebaiknya menggunakan pembelajaran yang aktif,efektif, menyenangkan sesuai dengan situasi dan kondisi yang ada;

2. Dengan melihat prestasi belajar siswa melalui metode penemuan yang mengalami peningkatan, tentunya bisa dikembangkan dengan metode pembelajaran yang lain yang dinggap lebih efektif.

\section{DAFTAR PUSTAKA}

Gatot Muhsetyo, dkk (2008) Pembelajaran Matematika SD. Jakarta: Universitas Terbuka

Moejiono dan Moh.Dimyati(1991) Strategi Belajar Mengajar.Jakarta: Depdikbud.Ditjen Pendidikan Tinggi Proyek Pembinaan Tenaga Kependidikan

Slamento (1993) Belajar Mengajar Dalam Proses Kredit Semester.Jakarta:Bumi Aksara

Roestiyah(1991) Strategi Belajar Mengajar. Jakarta : Rineka Cipta

Djayadisastra (1981) Metode-Metode Mengajar. Bandung : Angkasa

Muhaimin (1996) Strategi Belajar Mengajar.Surabaya : Citra Media 